\title{
Recent Hydro-Electric Developments in Northern Italy.
}

\author{
By Dr. Brysson Cunningham.
}

$\mathrm{I}^{\mathrm{N}}$ a preceding article (Sept. 6, p. 371), attention was directed to an essential difference in principle governing systems of hydro-electric development in the Alps and in the Apennines, distinguished in general terms as stations of high and of low altitude. Although my tour in Italy was confined to the northern provinces, and an opportunity was not forthcoming for inspecting developments actually among the Apennines, yet the installations visited within the Alpine region did, as a matter of fact, present certain characteristics of low altitude stations; that is to say, they were in some cases more dependent for supplies of water on rainfall and river flow than on the melting of ice and snow in glaciers.

The first installation inspected was that which constitutes the main source of energy of the Società per l'Utilizzazione delle Forze Idrauliche del Veneto, itself a branch of the great Società Adriatica di Elettricità, which is one of the largest in Italy and among the most important in Europe. It supplies current to a region of considerable extent, covering the whole of northeastern Italy comprised in the provinces of the three Venetias and Emilia, and stretching from the shores of Lake Garda to the confines of Yugoslavia. The undertaking derives its principal water supplies jointly from the River Piave and Lake Santa Croce, and develops power in a series of five stages from summit level at Lake Santa Croce to the outfalls at Castelletto and Caneva, where the discharge from these stations finally passes into the River Meschio, which conveys it to the sea. The power generated is transmitted at tensions of 70 to 120 kilovolts to the towns and cities of the districts served.

Lake Santa Croce, with its surface area of 8 square kilometres and its content of 120 million cubic metres of water, is one of the most capacious natural storage reservoirs in Italy. Together with one or two smaller sheets of water among the lower slopes of the Venetian Alps some 40 miles or so to the north of Venice, it lies adjacent to the upper basin of the River Piave, and there are indications that at some remote epoch it constituted part of the course of the river in its passage from the Carnic Alps to the Adriatic. The formation of a moraine across the head of the lake has apparently resulted in blocking the passage, and the waters of the Piave are now diverted in a south-westerly direction from a point in the river some five miles above the town of Belluno. Since this diversion took place, instead of feeding the lake as in times past, the Piave has been receiving the overflow from the latter in periods of flood.

Advantage has been taken of these circumstances to effect a joint service. At or about the point of diversion above alluded to, the level of which is some 1280 feet above sea-level, the bed of the Piave has been intersected by an earthwork embankment and masonry dam, to be seen in Fig. 1, with a combined length of rather more than half a mile. The dam provides an overflow crest for a length of about 300 yards, with a set of automatic adjustable weirs for relief in times of heavy flood. The water intercepted by the dam and weir is diverted into a canal on the eastern side of the river, which, partly in tunnel and partly in the open, conveys it a distance of six miles to the northern 
the power houses and pressure tubes is given in Fig. 2. In its complete development the new power station at Fadalto will possess a sixth unit of 24,500 horse power, making a total of 155,000 horse power generation under a maximum head of 348 feet.

The water discharged from the tail race at Fadalto passes into another natural lake of much smaller size-Lago Morto,or Dead Lake-which is utilised as a storage reservoir for the next stage of descent. The Dead Lake can provide 3 million cubic metres of water in the course of lowering its surface by 13 feet from 905 feet to 892 feet above sea-level. Leaving Lago Morto by a tunnel which is 2 miles in length, the water passes onwards to the power station at Nove, where there are four pressure tubes, $8 \mathrm{ft} .6 \mathrm{in}$. in diameter, connected up with three groups of generators of 22,000 horse power each

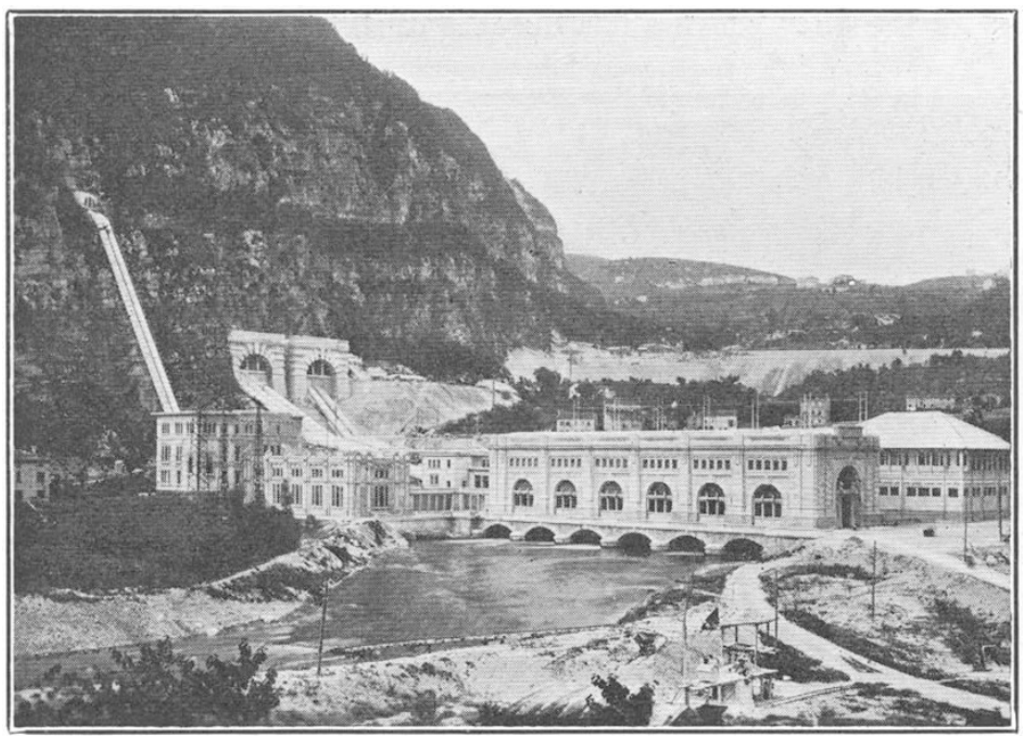

Fig. 2.- - Hydro-electric station at Fadalto.

By courtesy of the Societa per l'Utilizzazione delle Forze Idrauliche del Veneto.

Fadalto to Caneva serve at the present time to produce no less than 280,000 horse power, and with the extensions in view the total will shortly exceed 300,000 horse power.

The whole undertaking, comprising some 25 miles of waterway in canal, tunnel, river, and lake, with dams, shafts, buildings, and machinery, is a remarkable example of resourcefulness and technical skill in overcoming natural obstacles and constructional difficulties, such as beset in a rugged country the realisation of schemes for turning the forces of Nature to useful ends. The benefit to Italy of such undertakings is of the highest importance : every water horse power realised is the equivalent of about 6 tons of coal per annum, and the Piave-Santa Croce installation alone is capable of rendering unnecessary the annual importation of more than a million and a half tons of coal.

The supply of water being to a certain extent seasonal, there is inevitably a falling-off in production during certain winter months, and, accordingly, the Società Adriatica di Elettricità has to fall back on a thermic generating station as an auxiliary for such periods as the hydraulic supply is insufficient. This station is installed at the new industrial port of Marghera, Venice, and in its present form is capable of producing 86,000 horse power, with provision for future expansion as the need for additional current production manifests itself.

The second station visited was even more northerly than"Santa Croce ; it is right in the heart of the Dolomites, but here again the local conditions have conduced to the utilisation of a water supply derived from reasonably continuous river flow. The station belongs to the Società Idroelettrica

and two groups of 8000 horse power each, making a total capacity of 82,000 horse power for the station under a working head of 321 feet.

From Nove the water is directed into an artificial basin, designated Lake Restello, which has been formed out of a natural depression by means of a masonry dam. At its lower end, the supply under a head of $46 \mathrm{ft}$. reaches the station of San Floriano, where there is a small installation generating some 5000 horse power.

Leaving San Floriano, the water, after passing through the little lake of Negrisiola, enters a long canal which, partly in the open and partly in tunnel, conveys it a distance of 5 miles to Castelletto and 9 miles to Caneva, the two terminal stations of the development, from each of which the discharge passes into the River Meschio, where, as a final duty, it serves to irrigate a district containing 36 million hectares. The stations at Castelletto and Caneva develop 5000 and 60,000 horse power respectively. Thus it will be seen that the series of stations from dell' Isarco, which is linked up with the Società Idroelettrica Piemonte, one of the leading Italian concerns. The River Isarco, a tributary of the Adige, has a catchment basin above the town of Bolzano of some 3350 square kilometres. Hydrographic data collected over a period of about twenty years show that the mean winter flow (Nov. 1 to Mar. 31) ranges from 30 to 60 cubic metres per second; that the mean summer flow (April to November) ranges from 72 to 90 cubic metres per second, and that the average for the year lies between $56 \cdot 8$ cubic metres and $72 \cdot 6$ cubic metres. As theimean annual flow only occasionally ( 3 years in 19) falls below 60 cubic metres, it has been considered permissible to estimate that in conjunction with a working head of 163.50 metres at Cardano, where the generating station is located, a volume of electric energy amounting to 586 million $\mathrm{kwh}$. is capable of realisation, and this over a period of 7400 hours per annum reduces in round figures to 500 million $\mathrm{kwh}$., of which 210 million $\mathrm{kwh}$. are continuous.

No. 3178, VoL. 126] 
The river is bridled by means of a massive dam or embankment, ten miles north-east of Cardano and a little more from Bolzano, containing a set of three large sluices and a smaller sluice. The main sluices have openings 15 metres wide, the small sluice an opening 4 metres wide. Through the intake at the embankment, the water of the Isarco enters an accumulation and sedimentation basin with a serviceable capacity of 290,000 cubic metres, excavated in fairly level ground on the right bank of the river and provided with discharge outlets into the river capable of emptying it completely.

In the station itself are installed five generating groups of 45,000 horse power each and three groups of 14,700 horse power each, making an aggregate of about 270,000 horse power. The maximum demand, or peak load, will absorb the full capacity of four principal groups, leaving the fifth in reserve for the present. The whole of the energy, except the 25 million $\mathrm{kwh}$. generated by the smaller units, which will be supplied to the State railway for the electrified line from Bolzano to Brennero, will be transmitted at a tension of 240,000 volts to the transformer station of Cislago, near Milan, and thence distributed throughout the provinces of Lombardy and Piedmont.

The exceptionally great power of the installation and the unusually high tension of the transmission lines make the Cardano station of the Società Idroelettrica dell' Isarco one of the most notable stations in Europe. It is also remarkable as being the first plant in Europe working at so high a tension. This outstanding enterprise was brought into commission during 1929 , but at the time of my visit to the station, at the end of May last, there was still enough finishing work to be done to occupy several months.

The last station in my itinerary in Italy was the new Ponale installation in connexion with the utilisation of the waters of Lake Ledro, which lies rather less than 4 miles north-west of the head of Lake Garda, near Riva. The Ponale is the natural discharge of the overflow from the first lake into the second and there is a fall of 1800 feet between the two. Advantage had been taken of this fact by the municipality of Riva to construct a plant adjacent to the outfall at Ponale so early as $\mathbf{1 8 9 4}$. The plant was of small calibre and with gradual accretions only reached 2000 horse power in 1915 . The capabilities of the location were obviously very much greater and after the War considerable attention was given to the matter, the problem being whether to enlarge the existing station or to design an entirely new installation on lines of greater convenience and service.

Lake Ledro has an area of $2 \cdot 1$ square kilometres, with a catchment basin of 105 square kilometres. Its surface level is 654 metres above sea level, and it is fed by two subaqueous influents and two torrential streams. Its greatest depth is 48 metres and it has a content of 75 millions of cubic metres of water. It is obviously of glacial origin, and is blocked at the eastern end by a frontal moraine. It acts, therefore, as a suitable seasonal reservoir.

The matter was settled by the action of the com. bined municipality of Rovereto and Riva, which with expert advice decided upon an installation with a power station at Riva, and the works were commenced in November 1924. Discarding the old power station, a new conduit for the water has been formed by means of a tunnel 6 kilometres in length and 2.9 metres in diameter, running from a point near Mezzolago to an outlet near Riva, where the water enters two pressure tubes of $1 \cdot 15$ metres diameter for transmission to the power house at the edge of Lake Garda below. A view of the power house and pressure tubes is given in Fig. 3 .

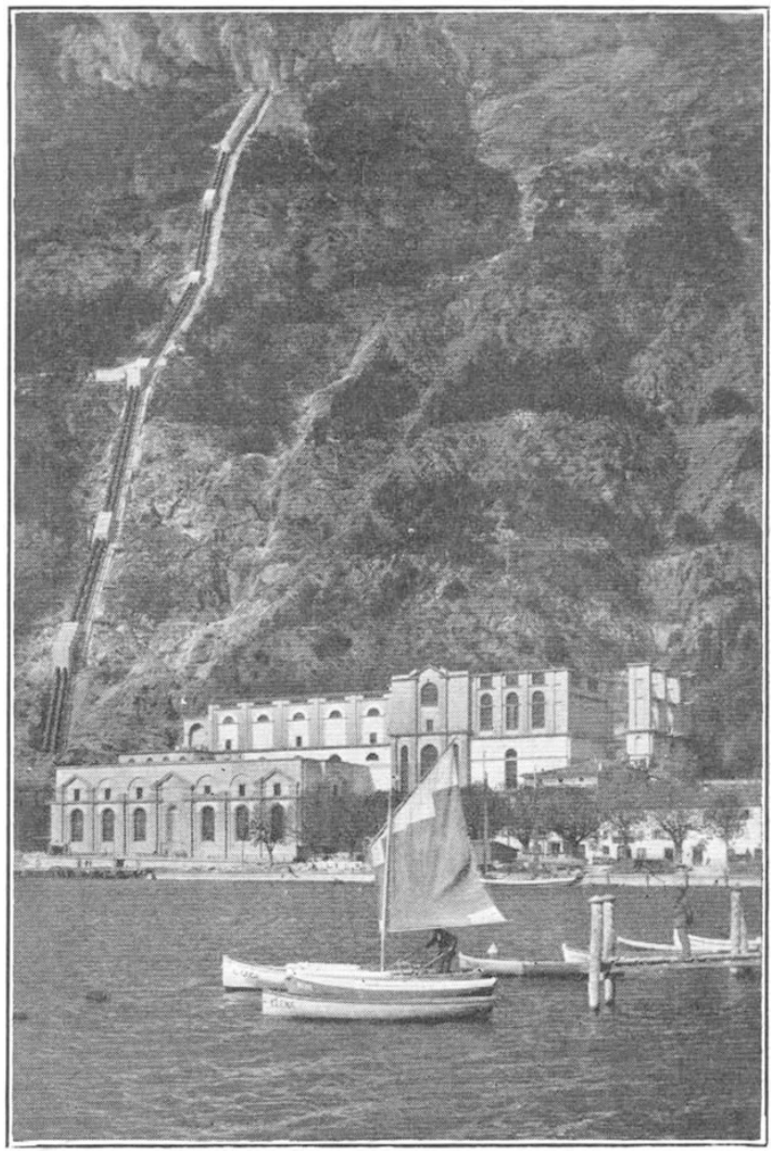

FIG. 3.-Hydro-electric station of the Ponale Installation at Riva, Lake Garda. By courtesy of the Consorzio Industriale delle Citta di Rovereto e Riva.

The power generating plant consists at present of two sets of Pelton water wheels, each with an output of 30,000 horse power, coupled to alternators of 21,000 kva. capacity. A third wheel of 45,000 horse power coupled with an alternator of $35,700 \mathrm{kva}$. is in course of installation and nearing completion. There is provision for a fourth unit.

The foregoing descriptions of plant and installations, which, despite their individual importance, form but a small portion of the activities of the Italian nation in regard to hydro-electric generation, will enable some idea to be formed of the projects which are now in hand and are playing so important a part in the industrial and commercial development of the country.

No. 3178, VoL. 126] 